\title{
FIVE NEW SPECIES OF NESOSELANDRIA ROHWER (HYMENOPTERA: SELANDRIINAE) FROM INDIA
}

\author{
M.S. Saini and V. Vasu
}

Department of Zoology, Punjabi University, Patiala, Punjab 147002, India

\begin{abstract}
Five new species of the genus Nesoselandria Rohwer are added to science from India. The taxonomic validity of these species has been supported by descriptions of morphology and genitilia, illustrations and detailed discussion.

\section{KeYwords}

Hymenoptera, India, Nesoselandria bengali sp. nov., N. fuscitarsus sp. nov., N. iari $s p$. nov., N. icar $s p$. nov., Selandriinae

\section{Abbreviations}

EL - Eye length; IATS - Inner apical tibial spur; ICD - Inter cenchri distance; IDMO - Interoocular distance at level of median ocellus; ITD - Inter tegular distance; LID - Lower interocular distance; MB - Metabasitarsus; OATS - Outer apical tibial spur; OCL - Oculooccipital line; OOL - Oculoocellar line; POL - Postocellar line.
\end{abstract}

Rohwer (1910) erected the genus Nesoselandria taking Paraselandria imitratix Ashmead as its type species from Phillipines. Again Rohwer (1915) added a new species to this genus from Calcutta, India. Malaise (1944) shifted Aneugmenus anandalei Rohwer and Neobusarbia flavipes Takeuchi to this genus. Benson (1939) erected a new genus Melisandra taking Selandria morio (Fabricius) as its type species from Holarctic region, but Smith (1969) synonymized it under Nesoselandria Rohwer. Malaise (1944) made two additions -- Nesoselandria sulciceps from Dehradun and N. turneri from Shillong. Some of the other important works concerning this genus from the oriental region include those of Enslin (1912), Rohwer (1916), Takeuchi (1928), and Forsius (1929, 1931a, 1931b, 1932, 1933), prior to which this genus was represented only by 22 species from this region. Only four species were on record from the Indian subcontinent. Following these contributions Saini and Vasu (1999), Vasu and Saini (1999a, 1999b), and Saini et al. (2001) added several new species to science under this genus from the Indian subcontinent. This genus is now represented by 25 species from India that includes the dealt herein five new species collected from the Himalayan region of northern and northeastern states. The present text deals with the descriptions and illustrations of the new species in question. The species are described following a standardized uniform pattern defined for the selandrine sawflies. Illustrations pertaining to genitalia and other morphological characters of taxonomic importance are provided. The host plants of these species remain unknown.

The genus Nesoselandria Rohwer is defined by a set of characters that follows: front wings with two radial and three or four cubital cells basalis and $1^{\text {st }}$ recurrent vein strongly converging; nervulus at apical third of cell; anal cell without crossvein. Hind wings with two closed middle cells and anellan cell mostly petiolate at the apex. Malar space linear to half diameter of median ocellus: Clypeus truncate to very shallowly emarginated; frontal area mostly poorly or not defined, subconvex; antennal furrows reduced to isolated lateral pits, sometimes transverse and communicating by a groove from one eye to the other; antennae slender, mostly filiform sometimes faintly incrassinated in middle, pedicel slender, almost as long as scape; $3^{\text {rd }}$ antennal joint longer than $4^{\text {th }}$ one; claws with acute but shorter basal lobe sometimes difficult to notice subapical tooth almost as long as or shorter than apical one.

The terminology used in this text is after Ross $(1937,1945)$ and Malaise (1945). The type materials of these species are housed at Division of Entomology, Pusa National Collections, Indian Agricultural Research Institute, New Delhi, India.

\section{Nesoselandia fuscitarsus sp. nov.}

(Figs. 1-5)

\section{Material examined}

Holotype: Female, 05.ix.1993, Elephant Falls, Meghalaya, 1500m, coll. V. Vasu.

Paratype: One female, 05.ix.1993, Elephant Falls, Meghalaya, 1500m, coll. V. Vasu; one female, 10.v.1986, Ranipool, Sikkim, $1600 \mathrm{~m}$, coll. M.S. Saini.

\section{Individual variation}

All specimens alike.

\section{Distribution}

India: Meghalaya, Sikkim.

\section{Etymology}

Species is named after its fuscous tarsi.

\section{Diagnostic features}

Black colour of tegula and abdomen with some tergites yellowish bring $N$. fuscitarsus sp. nov. close to $N$. rufiventris Rohwer. However, they can be set aside as malar space 1.0x diameter of median ocellus $(0.75 \mathrm{x}$ in latter), postocellar area wider than long as 2:1 (3:2 in latter), abdominal segments 2-5 aureate (abdomen entirely yellowish in female and basal six segments in male in latter), interocellar furrow absent (distinct in latter) and circumocellar furrow indistinct (distinct in latter). And also based upon the following combination of characters such as: labrum wider than long as 2:1, mesoscutellum almost flat metabasitarsus longer than following three joints combined as $4: 3$, ICD:ITD $=1: 6$, malar space $1 \mathrm{x}$ diameter of median ocellus, lateral furrows indistinct, and postocellar area wider than long as 2:1, N. fuscitarsus remains distinct from all other species 

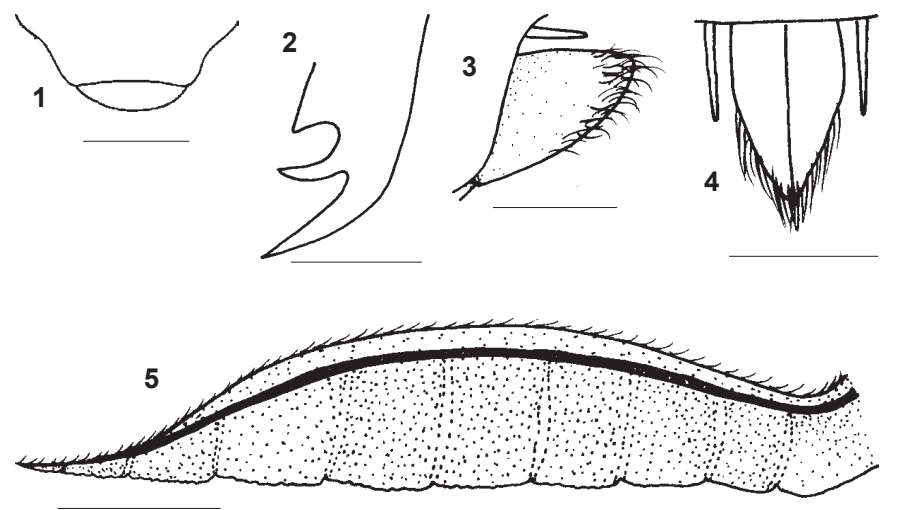

Figures 1-5. Nesoselandria fuscitarsus sp. nov. 1 - Clypeus and labrum; 2 - Tarsal claw; 3 - Lateral view of ovipositor sheath; 4 - Dorsal view of ovipositor sheath; 5 - Lancet. Scale $=0.5 \mathrm{~mm}$

described under this genus.

Female:

Colour: Body black, aureate are: tergites 2-5, sternites 2-5, all legs except infuscated extreme bases of coxae, apical rings of tibiae and tarsi. Wings hyaline, venation including costa, subcosta and stigma fuscous.

Structure: Length $6.0 \mathrm{~mm}$. Antenna $1.8 \mathrm{x}$ head width, scape equal to pedicel, segments three and four as 3:2; clypeus (Fig. 1) almost truncate, labrum (Fig. 1) broader than long as 2:1 with roundly pointed anterior margin; malar space $1 \mathrm{x}$ diameter of median ocellus; LID:IDMO:EL = 1.0:1:3:0:9, POL:OCL:OOL = 1.0:1.3:1.0; supraantennal pits deep and round, area between them smooth; frontal area flat, above level of eyes; median fovea in form of deep, oval pit above supraclypeal area; post and interocellar furrows absent, circumocellar furrows distinct; lateral furrows indistinct; postocellar area wider than long as 2:1; head parallel behind eyes; mesoscutellum almost flat, appendage ecarinate; ICD:ITD = 1.0:6.0; epicnemium separated from mesopleuron by fine furrow, tarsal claw (Fig. 2) with subapical tooth shorter than apical one, basal lobe distinct; metabasitarsus distinctly longer than following 3 joints combined as 4:3, IATS:MB:OATS: $=1.0: 2.6: 0.9$. Ovipositor sheath as in Fig. 3 (lateral view), Fig. 4 (dorsal view). Lancet (Fig. 5) having nine serrulae.

Sculpture: Body impunctate, shining.

Pubescence: Fuscous, 0.3x scape length.

Male: Yet to be discovered.

\section{Nesoselandia maculipoda sp. nov.}

(Figs. 6-10)

\section{Material examined \\ Holotype: Female, 02.v.1992, Elephant Falls, Meghalaya, 1500m, coll. V. Vasu.}

Paratype: One female, 02.v.1992, Elephant Falls, Meghalaya, $1500 \mathrm{~m}$, coll. V. Vasu.

\section{Individual variation}

Both specimens alike.

\section{Distribution}

India: Meghalaya.

\section{Etymology}

Species name alludes to its spotted legs.

\section{Diagnostic features}

The characters separating $N$. maculipoda sp. nov. from its allied species $N$. rufiventris Rohwer are femora, tibiae and basitarsi distinctly infuscated or reddish (entirely aureate in latter), postocellar area wider than long as 2:1 (3:2 in latter), tergites 35 and sternites 2-6 aureate (abdomen entirely yellowish in female and basal six segments in male in latter), frontal area flat (faintly depressed in latter), inter and circumocellar furrow fine (distinct in latter) and antennal segments three and four as 4:3 (3:2 in latter). And also based upon the following combination of characters such as: labrum wider than long as $2: 1$, mesoscutellum almost flat, metabasitarsus longer than following three joints combined as 4:3, ICD:ITD $=1.6$, malar space $1 \mathrm{x}$ diameter of median ocellus, lateral furrows indistinct, and postocellar area wider than long as $2: 1$, this species viz., N. fuscitarsus remains all distinct from all other species described under this genus.

\section{Female:}

Colour: Body black, aureate are: tergites 3-5, sternites 2-6. Legs brownish-yellow to fuscous, aureate are: all trochanters and adjoining parts of coxae, mesofemur. Wings hyaline, venation including costa, subcosta and stigma fuscous.
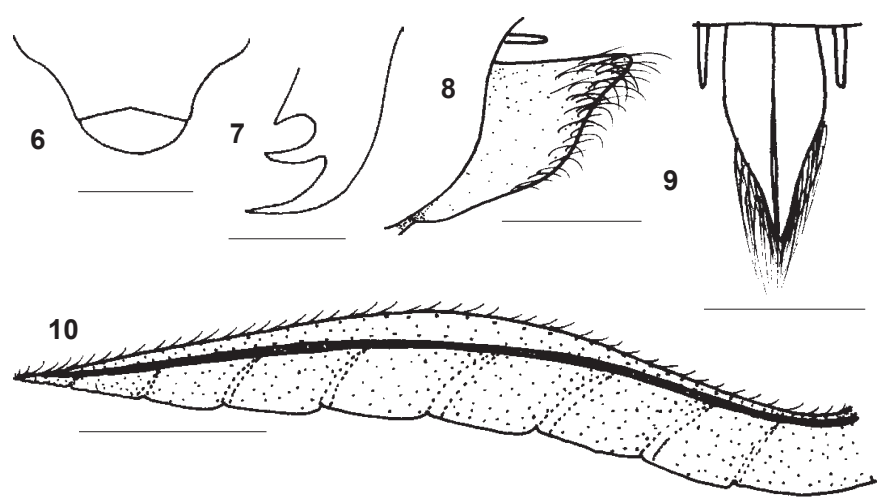

Figures 6-10. Nesoselandria maculipoda sp. nov. 6 - Clypeus and labrum; 7 - Tarsal claw; 8 - Lateral view of ovipositor sheath; 9 - Dorsal view of ovipositor sheath; 10 - Lancet. Scale $=0.5 \mathrm{~mm}$ 
Structure: Length $4.0 \mathrm{~mm}$. Antenna 1.6x head width, scape equal to pedicel, segments 3 and 4 as 4:3; clypeus (Fig. 6) shallowly emarginate, labrum (Fig. 6) broader than long as 3:2 with deflexed, rounded anterior margin, malar space $0.75 \mathrm{x}$ diameter of median ocellus, LID:IDMO:EL = 1.0:1.2:0.9, POL:OCL:OOL = 1.0:1.1:1.0; supraantennal pits deep and round, area between them smooth; frontal area flat, above level of eyes; median fovea in form of deep, transverse pit above supraclypeal area; postocellar furrow absent, inter and circumocellar furrows fine; lateral furrows fine, bulging medially and reaching hypothetical hind margin of head; postocellar area wider than long as 2:1; head narrowing behind eyes; mesoscutellum subconvex, appendage ecarinate; ICD:ITD = 1.0:5.0; epicnemium separated from mesopleuron by fine furrow; tarsal claw (Fig. 7) with subapical tooth shorter than apical one, basal lobe minute; metabasitarsus distinctly longer than following three joints combined as $4: 3$, IATS:MB:OATS: $=1.0: 2.8: 0.9$. Ovipositor sheath as in Fig. 8 (lateral view) and Fig. 9 (Dorsal view), Lancet (Fig. 10) having eight serrulae.

Sculpture: Body almost impuncutate, shining.

Pubescence: Fuscous, 0.4x scape length.

Male: Yet to be discovered.

\section{Nesoselandia icar sp. nov.}

(Figs. 11-17)

\section{Material examined Vasu. coll. M.S. Saini. \\ Individual variation \\ All specimens alike.}

Holotype: Female, Manipur; Ukhrul, 1700m, 19.v.1992, coll. V.

Paratype: Two males, 11.v.1993, Mirik, West Bengal, 1700m,

\section{Distribution}

India: Manipur, West Bengal.

\section{Etymology}

Species name is derived as an arbitrary combination of letters from the funding agency, Indian Council of Agricultural Research.

\section{Diagnostic features}

The characters such as: tegula, tergites 2-5 and sternites 2-6 aureate; segments three and four as $3: 2$; clypeus shallowly emarginate; malar space linear; POL:OCL $=1.0: 0.8$; frontal concave, above level of eyes; post and interocellar furrows absent; postocellar area wider than long as $2: 1$; ICD:ITD = 1.0:4.0; pubescence aureate and $0.4 \mathrm{x}$ scape length, set the species in question $N$. icar sp. nov. distinctly far apart from all the species described under this genus.

\section{Female:}

Colour: Body black, aureate are: tegula 2-5, tergites 2-5, sternites

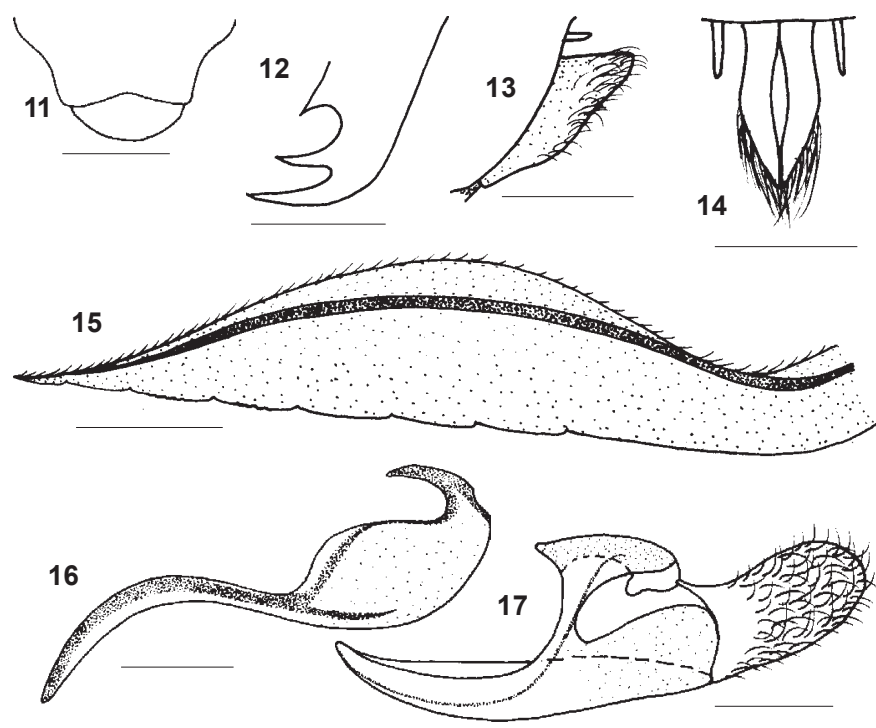

Figures 11-17. Nesoselandria icar sp. nov. 11 - Clypeus and labrum; 12 - Tarsal claw; 13 - Lateral view of ovipositor sheath; 14 - Dorsal view of ovipositor sheath; 15 - Lancet; 16 - Penis valve; 17 - Gonoforceps. Scale $=0.5 \mathrm{~mm}$

2-6; all legs except infuscated apical three tarsal joints of mesolegs, and apical four tarsal segments including extreme apex of basitarsus of metalegs. Wings hyaline, venation including costa, subcosta and stigma fuscous.

Structure: Length 5.0mm. Antenna 1.7x head width, scape equal to pedicel, segments three and four as 3:2; clypeus (Fig. 11) Shallowly emarginate, labrum (Fig. 11) broader than long as 3:2 with rounded anterior margin; malar space linear; LID:IDMO:EL $=1.0: 1.4: 1.2$, POL:OCL:OOL = 1.0:0.8:1.0; supraantennal pits deep and round, area between them smooth; frontal concave above level of eyes; median fovea in form of shallow depression above supraclypeal area; post and interocellar furrows absent, circumocellar furrows fine, lateral furrows distinct, bulging medially and ending just before hypothetical hind margin of head; postocellar area wider than long as 2:1; head narrowing behind eyes; mesoscutellum subconvex; appendage ecarinate; ICD:ITD = 1.0:4.0; epicnemium separated from mesopleuron by fine furrow; tarsal claw (Fig. 12) with subapical tooth shorter than apical one, basal lone minute; metabasitarsus longer than following three joints combined as 5:4; IATS:MB:OATS: = 1.0:3.0:0.9. Ovipositor sheath as in Fig. 13 (lateral view), Fig. 14 (dorsal view). Lancet (Fig. 15) having seven serrulae.

Sculpture: Body almost impunctate, shining.

Pubescence: Aureate, 0.4x scape length.

Male: Average length $4.5 \mathrm{~mm}$. Similar to female. Genitalia: Penis valve (Fig. 16) gonoforceps (Fig. 17). 


\section{Nesoselandria bengali sp. nov.}

(Figs. 18-24)

\section{Material examined \\ Holotype: Female, 11.v.1993, Mirik, West Bengal, 1600m, coll. V. Vasu. \\ Paratypes: One female, one male, 11.v.1993, Mirik, West Bengal, 1600m, coll. V. Vasu; one female, 26.v.1989, Darjeeling, West Bengal, 2200m, coll. M.S. Saini; one female, 13.v.1994, Pfutsero, Nagaland, 2100m, coll. V. Vasu.}

\section{Individual variation}

All specimens alike.

\section{Distribution}

India: West Bengal, Nagaland.

\section{Etymology}

Species name is derived from the name of the state in which the type locality is situated.

\section{Diagnostic features}

On the basis of some outstanding key characters such as: abdomen brownish to black at least above, legs with some broad pale yellow markings, and area between supraantennal pit smooth $N$. bengali sp. nov. is closely related to $N$. annandalei (Rohwer). Bur the two can be separated as: abdomen with tergites two to basal $1 / 2$ of five yellow (entirely black in latter), malar space $0.6 \mathrm{x}$ diameter of median ocellus (linear in latter), antennal segments three and four as 3:2 (5:4 in latter), scape equal to pedicel (longer than in latter), postocellar area wider
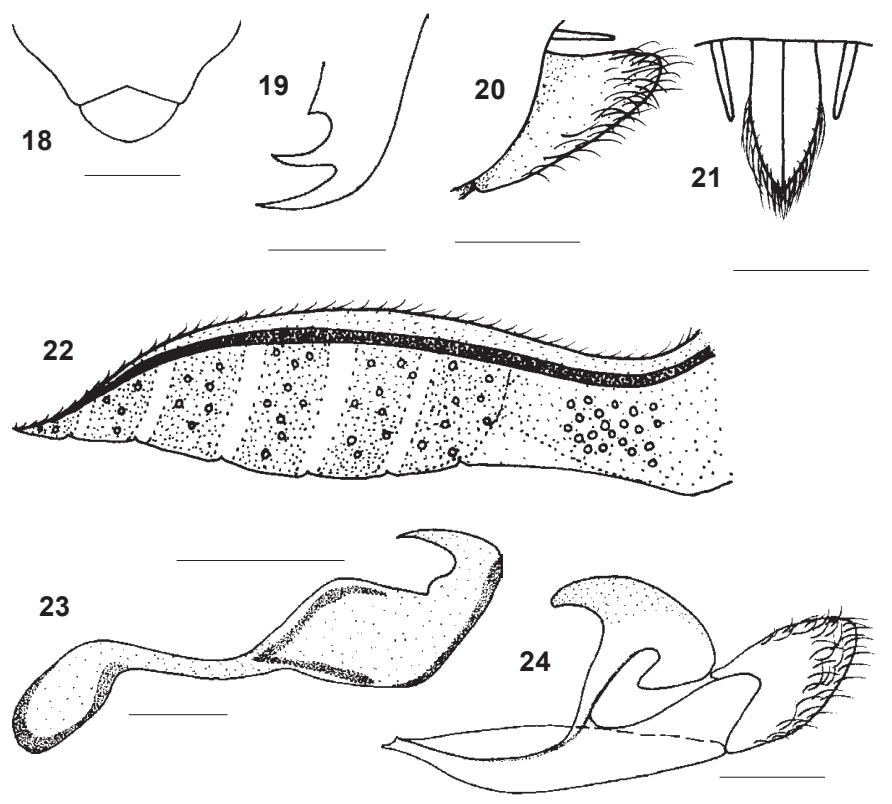

Figures 18-24. Nesoselandria bengali sp. nov. 18 - Clypeus and labrum; 19 - Tarsal claw; 20 - Lateral view of ovipositor sheath; 21 - Dorsal view of ovipositor sheath; 22 - Lancet; 23 - Penis valve; 24 - Gonoforceps. Scale $=0.5 \mathrm{~mm}$ than long as 2:1 (3:1 in latter), inter- and circumocellar furrows distinct (indistinct in latter), lateral furrows distinct (shallow in latter), and clypeus triangularly emarginated (arcuately emarginated in latter).

\section{Female:}

Colour: Body black, aureate are: tergites $2-4$, basal $1 / 2$ of tergite five, all legs except infuscated apical 2 tarsal joints. Wings hyaline, venation including costa, subcosta and stigma fuscous.

Structure: Average length 4.5mm. Antenna 1.6x head width, scape equal to pedicel, segments 3 and 4 as 3:2; clypeus (Fig. 18) triangularly emarginate, labrum (Fig. 18) broader than long as $2: 1$ with rounded anterior margin; malar space $0.6 \mathrm{x}$ diameter of median ocellus; LID:IDMO:EL = 1.0:1.3:1.3, POL:OCL:OOL = 1.0:0.8:0.8; supraantennal pits deep and round, area between them smooth; frontal flat, at level of eyes; median fovea in form of distinct transverse pit above supraclypeal area; postocellar furrow absent, inter- and cirumocellar furrows distinct; lateral furrows distinct diverging posteriorly and ending half way to hypothetical hind margin of head postocellar area wider than long as 2:1; head narrowing behind eyes; mesoscutellum subconvex, appendage ecarinate; ICD:ITD = 1.0:6.0; epicnemium separated from mesopleuron by fine furrow; tarsal claw (Fig. 19) with subapical tooth shorter than apical one basal lobe minute, metabasitarsus longer than following three joints combined as 4:3, IATS:MB:OATS:= 1.0:2.6:0.9. Ovipositor sheath as in fig. 20 (lateral view), fig. 21 (dorsal view). Lancet (Fig. 22) having six serrulae.

Sculpture: Body almost impunctate, shining.

Pubescence: Aureate, $0.5 x$ scape length.

Male: Average length $3.5 \mathrm{~mm}$. Similar to female. Genitalia: Penis valve (Fig. 23), gonoforceps (Fig. 24).

\section{Nesoselandia iari sp. nov.}

(Figs. 25-29)

\section{Material examined}

Holotype: Female, 07.v.1994, Tissa, Arunachal Pradesh, 700m, coll. M.S. Saini.

Paratype: One female, 03.05.1992, Jowai, Meghalaya, 1500m, coll. V. Vasu.

\section{Individual variation}

Both specimens alike.

\section{Distribution}

India: Arunachal Pradesh, Meghalaya.

\section{Etymology}

Species name is derived as an arbitrary combination of letters from the Indian Agricultural Research Institute, where the type material is housed. 

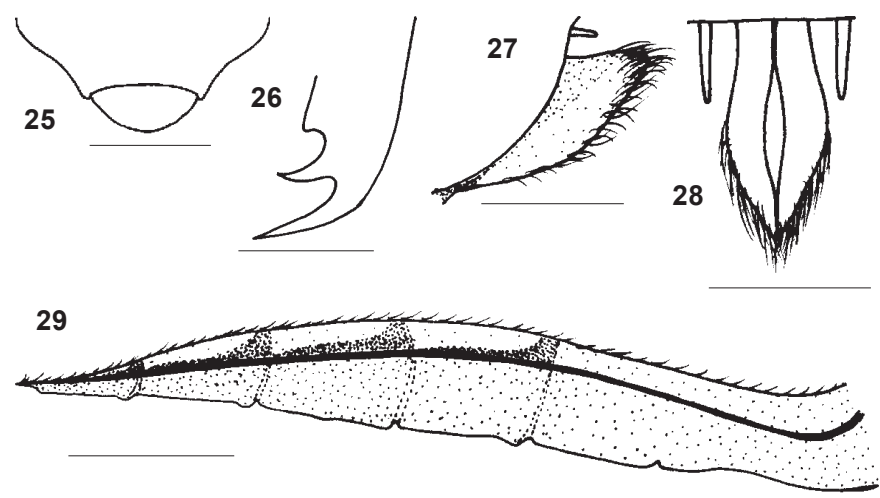

Figs. 25-29. Nesoselandria iari sp. nov. 25 - Clypeus and labrum; 26 - Tarsal claw; 27 - Lateral view of ovipositor sheath; 28- Dorsal view of ovipositor sheath; 29 - Lancet. Scale $=0.5 \mathrm{~mm}$

\section{Diagnostic features}

$N$. iari sp. nov. is allied to $N$. icar sp. nov. from which it can be set apart as: scape and pedicel yellow, tergites 3-5 yellow, circumocellar furrow absent, lateral furrows fine and indicated just behind lateral ocelli in former whereas scape and pedicel black, tergites 2-5 yellow, circumocellar furrow fine, lateral furrows distinct and ending just before hypothetical hind margin of head in latter. On the other hand this species does not come close to any of the Oriental species described under this genus so far. The characters of taxonomic significance to keep it far apart from all other species are: clypeus circularly emarginate, malar space linear, IDMO:EL = 1.0:1.0, POL:OCL:OOL $=$ 1.0:0.8:0.7, frontal flat and above level of eyes; median fovea in form of distinct transverse pit, post-, inter- and circumocellar furrows absent; lateral furrows fine and indicated just behind lateral ocelliand lancet having five serrulae .

\section{Female:}

Colour: Body black, aureate are: scape, pedicel, tegula, tergites two except broad lateral spots, tergites 3-5 entirely, sternites 26; all legs except infuscated apical three tarsal joints of metalegs. Wings hyaline, venation including costa, subcosta and stigma fuscous.

Structure: Length 5.0mm. Antenna 1.7x head width, scape equal to pedicel, segments three and four as 5:4; clypeus (Fig. 25) circularly emarginate, labrum (Fig. 25) broader than long as 3:2 with rounded anterior margin, malar space linear; LID:IDMO:EL $=1.0: 1.5: 1.5$, POL:OCL:OOL $=1.0: 0.8: 0.7$; supraantennal pits deep and round, area between them smooth, frontal flat, above level of eyes; median fovea in form of distinct transverse pit above supraclypeal area: post-, inter- and circumocellar furrows absent; lateral furrows fine and indicated just behind lateral ocelli; postocellar area wider than long as $2: 1$; head narrowing behind eyes; mesoscutellum subconvex, appendage ecarinate; ICD:ITD = 1.0:5.0; epicnemium separated from mesopleuron by fine furrow; tarsal claw (Fig. 26) with subapical tooth shorter than apical one, basal lobe minute; metabasitarsus longer than following three joints combined as 4:3, IATS:MB:OATS:= 1.0:3.0:0.9. Ovipositor sheath as in Fig. 27 (lateral view), Fig. 28 (dorsal view). Lancet (Fig. 29) having five serrulae.

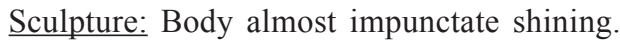

Pubescence: Aureate, $0.4 \mathrm{x}$ scape length.

Male: Yet to be discovered.

\section{REFERENCES}

Benson, R.B. (1939). Four new genera of British sawflies (Hym., Symphyta). Entomologist's Monthly Magazine 75: 110-113.

Enslin, E. (1912). Edward Jacobson's Java-Ausbeute, Fam. Tenthredinoidea (Hym.) nebst Bestimmungstabelle der einschlagigen Gattungen. Tijdschrift voor Entomologie 55(5): 104-126.

Forsius, R. (1929). Ueber neue order wenig bakannte Tenthredinoidea aus Sumatra. Notulae Entomologicae 9: 53-70.

Forsius, R. (1931a). Notes on a collection of Ethiopian Oryssoidea and Tenthredinoidea (Insecta: Hymenoptera). The Annals and Magazine of Natural History 8(10): 1-36.

Forsius, R. (1931b). Enie neue Machrophya aus, China (Hym., Tenth). Notulae Entomologicae 59: 29-48.

Forsius, R. (1932). Eine neue Anapeptamena Art aus Formosa (Hymenoptera, Tenthredinoidea). Notulae Entomologicae 12: 51-53.

Forsius, R. (1933). Notes on a collection of Malaysian Tenthredinoidea (Hymenoptera). Bulletin of the Raffles Museum 8: 169-193.

Malaise, R. (1944). Entomological results from the Swedish Expedition 1934 to Burma and British India. Hymenoptera, Tenthredinoidea. Arkiv for Zoology 35A(10): 1-58.

Malaise, R. (1945). Tenthredinoidea of South-eastern Asia with a general Zoogeographical review, Opuscula Entomologica, Supplement, IV: $288 \mathrm{pp}$.

Rohwer, S.A. (1910). Some new Hymenopterous insects from the Philippine Islands. Proceedings of the United States National Museum 37: 657-660

Rohwer, S.A. (1915). Some Oriental sawflies in the Indian Museum (Hymenoptera). Records of the Indian Museum, Calcutta 11: 39-53.

Rohwer, S.A. (1916). H. Sauter's Formosa Ausbeute Chalastogastra (Hym.). Supplementa Entomologica 5: 81-113.

Ross. H.H. (1937). A generic classification of the Nearctic sawflies (Hymenoptera: Symphyta). Illinois Biological Monographs 34: 1-173. Ross, H.H. (1945). Sawfly genitalia: Terminology and study techniques. Entomological News 56: 261-268.

Saini, M.S. and V. Vasu (1999). Addition of three new species of Nesoselandria Rohwer to the Indian fauna (Hymenoptera, Symphyta, Tenthredinidae, Selendriinae). Entomologische Mitteilungen aus dem Zoologischen Museum, Hamburg 13(159): 13-21. Hamburg.

Saini, M.S., T.P. Saini and V. Vasu (2001). Revision of genus Nesoselandria Rohwer from India (Hymenoptera, Symphyta, Tenthredinidae, Selandriinae). Zoos' Print Journal 16(11): 615-629.

Smith, D.R. (1969). Nearctic sawflies II Selandriinae; Adults. (Hymenoptera: Tenthredinidae). Agricultural Research services, United States Department of Agriculture Technical Bulletin 1398: 48pp.

Takeuchi, K. (1928). New sawflies from Formosa - II. Transactions of the Natural History Society Formosa 18(94): 38-45.

Vasu, V. and M.S. Saini (1999a). New records of Nesoselandria Rohwer from India (Hymenoptera, Symphyta, Tenthredinidae: Selandriinae). Folia Entomologica Hungarica 60: 261-268.

Vasu, V. and M.S. Saini (1999b). Two new species to the genus Nesoselandria Rohwer, 1910 (Hymenoptera: Symphyta: Tenthredinidae: Selandriinae) from India. Russian Journal of Entomology 8(2): 131-133.

\section{ACKnowledgements}

The authors are highly thankful to Dr. D.R. Smith, U.S. Department of Agriculture, Washington, D.C., U.S.A. for his valuable suggestions. Financial assistance rendered by US, PL-480 in coordination with ICAR, New Delhi is also acknowledged with thankfulness. 